\title{
Proceeding
}

Supplementary Issue: Autumn Conferences of Sports Science. Costa Blanca Sports Science Events, 18-19 December 2020. Alicante, Spain.

\section{Basis of economic security of a highly qualified athlete}

\author{
PAVEL SERGEEVICH PROBIN ${ }^{1}$, ARKADII ANATOL'EVICH SIMDIANKIN ${ }^{1}$, ANGELINA OLEGOVNA \\ ZEKIY², NATALIA ALEKSEEVNA PRODANOVA ${ }^{3}$, SVETLANA NIKOLAEVNA POZDEEVA4, IRINA \\ EDWARDOVNA GURYANOVA4 \\ ${ }^{1}$ Russian State University of Physical Education, Sport, Youth and Tourism (SCOLIPE), Moscow, Russian Federation \\ ${ }^{2}$ Department of Prosthetic Dentistry, Sechenov First Moscow State Medical University, Moscow, Russian Federation \\ 3Plekhanov Russian University of Economics, Moscow, Russian Federation \\ ${ }^{4}$ Financial University under the Government of the Russian Federation, Moscow, Russia
}

\begin{abstract}
At the present stage issues of ensuring personal economic security are becoming particularly relevant and especially it is important in the context of local and global pandemics. This problem area has a complex character, and it is characterized by its multiplicity that determines the necessity to study the relevant issues in the context of the professional identity of the individual. From our point of view the most interesting feature is the development of problems of personal economic security in the physical culture and sports industry. It is worth taking into account the fact that the problems of ensuring economic security in the physical culture and sports industry are in most cases considered at the level of major manufacturers of sports products, international sports organizations and the state. In this regard the issues of ensuring personal economic security of professional athletes as subjects of international sports remain largely outside the scope of these studies. This circumstance clearly demonstrates the fact that there is a "dialectical gap" between the sphere of economic security in the physical culture and sports industry and the issues of personal economic security of professional athletes that directly influences on the prospects for the development of spectator sports and sports of higher achievements.

Keywords: Economic security; Entrepreneurship in sports; Financial control; Personal finance; Prize payments; Professional sports; Top-level sports.

Cite this article as:

Probin, P.S., Simdiankin, A.A., Zekiy, A.O., Prodanova, N.A., Pozdeeva, S.N., \& Guryanova, I.E. (2021). Basis of economic security of a highly qualified athlete. Journal of Human Sport and Exercise, 16(2proc), S485-S498. doi:https://doi.org/10.14198/ihse.2021.16.Proc2.33

Corresponding author. Department of Prosthetic Dentistry, Sechenov First Moscow State Medical University, Trubetskaya St., 8-2, 119991, Moscow, Russian Federation.

E-mail: anas.kurilova@mail.ru

Abstract submitted to: Autumn Conferences of Sports Science. Costa Blanca Sports Science Events, 18-19 December 2020. Alicante, Spain.

JOURNAL OF HUMAN SPORT \& EXERCISE ISSN 1988-5202

(C) Faculty of Education. University of Alicante

doi:10.14198/jhse.2021.16.Proc2.33
\end{abstract}




\section{INTRODUCTION}

Personal economic security of professional athletes is characterized by a wide range of specific features. In turn the modern mechanism of market relations clearly shows its influence in the field of professional sports: in some cases, a low degree of effectiveness of financial support contributes to the migration of professional athletes with a subsequent change of residence. This is in many ways not only a local problem (in the context of a particular sport) but also causes significant damage to the country's reputation. The correlation between the country's image in the international arena and the achievements of leading athletes in international competitions is beyond doubt. The destructive consequences of an athlete's change of citizenship for the state are more obvious and open than, for example, the migration of scientific personnel and highly qualified specialists. This is due to the fact that in the second case, these processes occur in a hidden form and the negative consequences are unevenly distributed over time. This is what makes it very difficult to assess them objectively in a real time.

The study of the problem of personal economic security of a professional athlete is a very difficult task since it lies both in the plane of evaluating the effectiveness of financial incentives formed at the state level and in plane of inquiry of market relations on the subject under consideration.

The selective nature of state support for individual sports that combined with an insufficiently high level of wages in a particular sport and a high level of competition determines the relevance of the problem of finding optimal methods to ensure the personal economic security of a professional athlete. At the same time, the approach to diversifying the sources of income of athletes to public and private - especially in the perspective of the economic crisis - seems to us correct but it needs significant structural changes. For example, the implementation of a private business initiative that is not directly related to the provision of services in the field of physical culture and sports as well as the development of the institution of private sponsorship can become not only alternative sources of income generation for athletes. In the future they will take on the role of leading satellites of the financing mechanism for professional sports and high-performance sports at the level of a single territorial unit. In other words, we can observe a "reverse" positive economic effect - the key element of the economic security system in the physical culture and sports industries is the personal economic security of professional athletes.

\section{LITERATURE REVIEW}

The economic security of the physical culture and sports industry is an element of the national security system. A significant number of works of domestic and foreign specialists-practitioners and scientistseconomists are devoted to the topic of economic security. At the same time, it should be noted that the format of research on these issues in each individual case has its own distinctive features.

The country's economic security is determined by a wide range of indicators: GDP, rate of inflation, trends in foreign trade, monetary policy and so on. At the same time, the development of the infrastructure of the national financial market, the national payment system and the national payment card system are among the most pressing issues in this area (Filatova, 2017; Turgaeva et al., 2020). In the light of active digitalization, the topic of ensuring economic security of transactions also becomes particularly relevant (Sylvanus \& Adepele, 2019; Bukharina et al., 2014). Resistance to external and internal crisis phenomena is a direct indicator of the effectiveness of the economic security system both at the state level (Blakyta \& Ganushchak, 2018) and at the level of a group of companies, an economic entity (Melnyk et al, 2020). All of these options 
can indicate an objective need to develop effective assessment tools (Klychova et al, 2019; Tarman, 2016; Ivanova et al., 2019; Dunets et al. 2019, 2020).

Taking personal economic security as a starting point in the study we can formulate a hypothesis that it is a determining factor in the development of the sphere of economic security of sports. As a result, it is objective and justified to consider it both at the level of an independent object for research and from the point of view of assessing its impact on the overall synergetic effect of the functioning of the system of economic security of sports in the country.

The idea that the security of a system is determined not by environmental factors but directly by the level of security of its individual (primary) elements is widely spread in the scientific literature. In particular, this situation can be seen in the example of the state's economic security system (Ruhovets, 2016; Masood et al., 2019): savings capital of individuals is the most important source of investment that could be mobilized through the securities market and financial and credit institutions and subsequently directed to the development of the real sector of the economy. In other words, the problems of the country's economic security are largely reflected not only in international economic relations, but also in the perspective of the financial well-being of individual social groups and individuals (Pryazhnikova, 2017; Dzhavatov et al., 2018). It is important to note that economic security has a complex socio-economic nature and can be positioned as a community value (Beilin, 2014). So, the approach that assumes the study of personal economic security solely as a phenomenon that can be unambiguously quantified through standard economic indicators and procedures is presented to us as superficial and not reflecting the full diversity of the issues under consideration (Sylvanus et al., 2019; Kuzmin et al., 2018; Sedov et al., 2014).

In a special order the scientific literature should consider the issues of economic security of professional athletes. This is due to the fact that today sport is a stable driver of economic growth because it is based on the formation of investment potential and this is extremely important in the context of the crisis and the high dependence of the national economy on oil and gas raw materials. Moreover, the scale of state funding for physical culture and sports shows a growing trend. As a result, we could talk about increasing the economic security of physical culture and sports in general. However, this circumstance is not always objectively reflected in the level of prosperity of a particular professional athlete. Since professional and spectator sports are characterized by the fact that the personality of an athlete is perceived by society, sponsors, mass media and international organizations in direct relationship with his country of residence it can be concluded that issues of personal economic security have a direct, significant impact on the economic security of domestic sports as a whole. Thus, we can conclude that the study of issues related to improving the economic security of sports is not only in the sphere of state funding programs but also in the sphere of personal economic security of athletes.

\section{METHODS}

It is important to note that the conceptual framework in this area needs to be clarified since the current stage of development of the physical culture and sports industry market - as well as the modern model of international economic relations - determine a qualitatively new format of requirements for understanding economic security. As a result, there is an objective need to detail its interpretation not only in the perspective of individual sectors of the economy but also in terms of its understanding as a stable state of its primary carriers. In this case we are talking about the need to introduce a definition of both personal economic security of the athlete and economic security during sports competitions/events. In most cases these issues are not reflected in scientific works on the subject of sports economics. In addition, a full and comprehensive 
understanding of the essence of personal economic security of an athlete and economic security during sports competitions/events is necessary first of all to make an objective and reasonable decision by a potential sponsor about the possibility of supporting a professional athlete/sports event (competition).

The authors suggest that the economic security of athletes is understood as a system of financial measures that guarantee the comprehensive readiness of athletes to achieve top scores at competitions of various levels during the entire period of dynamic athletic activity.

Accordingly, the economic security of sports competitions/events should be understood as the stable nature of financial relationships between state authorities, local governments, commercial and non-commercial sports organizations, educational and medical institutions, participants in the financial sector of the economy as well as companies that provide technical, sponsorship and other support to professional athletes and visitors to sports competitions/events that ensure the achievement of a high socio-economic effect both by meeting the needs of all its participants and by creating additional investment potential and a positive tourist, cultural and leisure image of the region/host country.

State programs for the development of physical culture and sports have allowed to form a "vector" of sustainable growth in the studied area that is reflected in the setting to work of a significant number of sports facilities over the past few years. This, in turn, contributed to the creation of additional jobs and the active involvement of private businesses in supporting the activities of sports infrastructure facilities. There is a tendency to replace public expenditures on financing the maintenance of fixed-capital assets in the field of physical culture and sports with private capital (Voronina, 2017; Poltarykhin et al., 2020). In other words, the dynamic nature of the development of physical culture and sports has determined the need to create an alternative model of interaction between the state and the private sector where the main purpose would be to form qualitatively new approaches to ensuring the economic security of all its participants. No doubt sports infrastructure facilities play a crucial role in this area - when having successfully realized their potential during the winter Olympic Games in Sochi and the world Cup they should take over the functions of financial centres and business incubators in the foreseeable future. It being understood the main task of these incubators will be to implement cost-effective projects with the participation of public and private capital which would greatly contribute to the subsequent improvement of economic security not only for investors but also for professional athletes themselves. Thus, the relationship between the effective development of sports infrastructure facilities and the economic security of the state, private business and representatives of the professional sports community is objectively traced (it is with their participation that the development of a system of individual sports brands is possible in the future).

It is known that the fraction of income from the sale of merchandise in the total revenue structure of a professional sports organization corresponds to about $15 \%$ while positive sports results can provide an increase in income by more than $20 \%$ (Feofanov, 2005). In addition, the level of authority of leading athletes has a direct impact on the sale of merchandise (Feofanov, 2005). Also, in the history of modern game sports there are cases when sales of merchandise exceeded revenues from TV rights ("Spartak" for the first-time disclosed revenues from ticket sales and TV rights, 2018).

In the situation we are considering it seems possible to combine the function of merchandise in sports products (for example, a kimono issued under the brand of a leading athlete is both a sports uniform and merchandise). In turn, the level of costs for the development of your own brand can be minimal, for example, at the initial stage of such projects it makes sense not to organize your own production but to form an individual order from leading manufacturers of sporting goods with the appropriate logo and/or make your 
own design suggestions (this approach is actively used by leading manufacturers of snowboards when promoting pro-models of athletes of international level). In this case, the athlete himself becomes an entrepreneur and the ideas man of "success" of the brand since his performance will depend on the potential income from the sale of sports goods under his brand and income from contracts signed with sponsors. This approach follows the implementation of the generally accepted KPI approach while the level of prosperity of a sportsman increases with his successful performances and the share of state support and income from private professional activities in the total "income basket" decreases due to the stable level of sales of sporting goods and income from sponsorship.

The model of economic security of a professional athlete is based on the principle of diversification of income sources. At the same time, the key factor is the dependence of its achievements on the revenue for the sale of sports products under its brand and the degree of attractiveness for sponsors. In this case, the financial support of the state, on the contrary, is reduced to the necessary minimum. Under these conditions the athlete himself is interested in demonstrating his maximum achievements on the national and international stage since the level of potential income is not limited by anything except for fluctuations in the market for sporting goods. This approach will create a reserve of financial security and will help reduce the number of athletes who want to change their country of residence due to the low level of wages in the professional sphere.

Since the country factor has a significant impact on the amount of financial support for athletes by the state it is advisable to introduce a flexible model for assessing the personal economic security of professional athletes based on a combination of qualitative and quantitative approaches.

We use the following function to evaluate the level of economic security:

$$
f\left(P_{1}, P_{2}, P_{3}, Q_{1}, Q_{2}, Q_{3}\right)=\sum_{i=1}^{3} P_{i} Q_{i}
$$

where $P_{1}, P_{2}, P_{3}$ - sources of income for a professional athlete;

$Q_{1}, Q_{2}, Q_{3}$ - raiting coefficients of payments in the total income "baskef" of a professional athlete.

Parameters $Q_{i}, i=1,2,3$ are determined in advance at the first stage of expert evaluation (Delphi method).

$$
\sum_{i=1}^{3} Q_{i}=1, \quad Q_{i} \in[0,1]
$$

In the second stage the experts define the parameter values $P_{i}, i=1,2,3$ so that the following condition is met:

$$
f\left(P_{1}, P_{2}, P_{3}, Q_{1}, Q_{2}, Q_{3}\right) \leq 1
$$

It should be emphasized that the higher the value of the function the higher the level of economic security.

The values of each parameter $(P)$ are in the range from 0 to 1 and they can be changed based on specific economic conditions. They are assigned based on a set of economic indicators such as the level of wages in the country/region; the level of wages in the field of physical culture and sports; the cost of a food basket, etc. An approximate range of values is shown in Table 1. 
Note that the final indicator $f$ (it tends to one in its maximum value that corresponds to the highest level of economic security) also needs not only a generalized but also a structural assessment. In the proposed model the number of parameters may vary. In this case, everything depends on the specific sport and its public and private support measures in the country of residence. According to the structure of the indicator the optimal ratio of income in the total income basket of a professional athlete will be considered when the deductions from sponsorship contracts and the sale of attributes will exceed payments from the state and/or income in the private sector from professional activities.

However, in the current economic conditions - regardless of the country of residence - it seems appropriate to reduce the dependence on the factor of state support by activating the entrepreneurial initiative of the most successful professional athletes.

Table 1. Matrix of the significance of the source of income in the system of economic security of a professional athlete.

\begin{tabular}{lccc}
\hline \multirow{2}{*}{ Value of source income } & \multicolumn{3}{c}{ Regularity of receipts } \\
\cline { 2 - 4 } & $\begin{array}{c}\text { Insignificant } \\
\text { income }\end{array}$ & $\begin{array}{c}\text { Mid-level } \\
\text { income }\end{array}$ & $\begin{array}{c}\text { Significant amounts of } \\
\text { income }\end{array}$ \\
\hline $\begin{array}{l}\text { One-time payments for the period } \\
\text { Multiple payments during the }\end{array}$ & 0 & 0.25 & 0.5 \\
period & 0.25 & 0.5 & 0.75 \\
Stable system of payments & 0.5 & 0.75 & 1 \\
\hline
\end{tabular}

\section{IMPLEMENTATIONS AND CONCLUSION}

The traditional approach to building the economic security of leading athletes (Figure 1) does not seem to fully meet the modern realities of the market economy and, of course, needs to be improved.

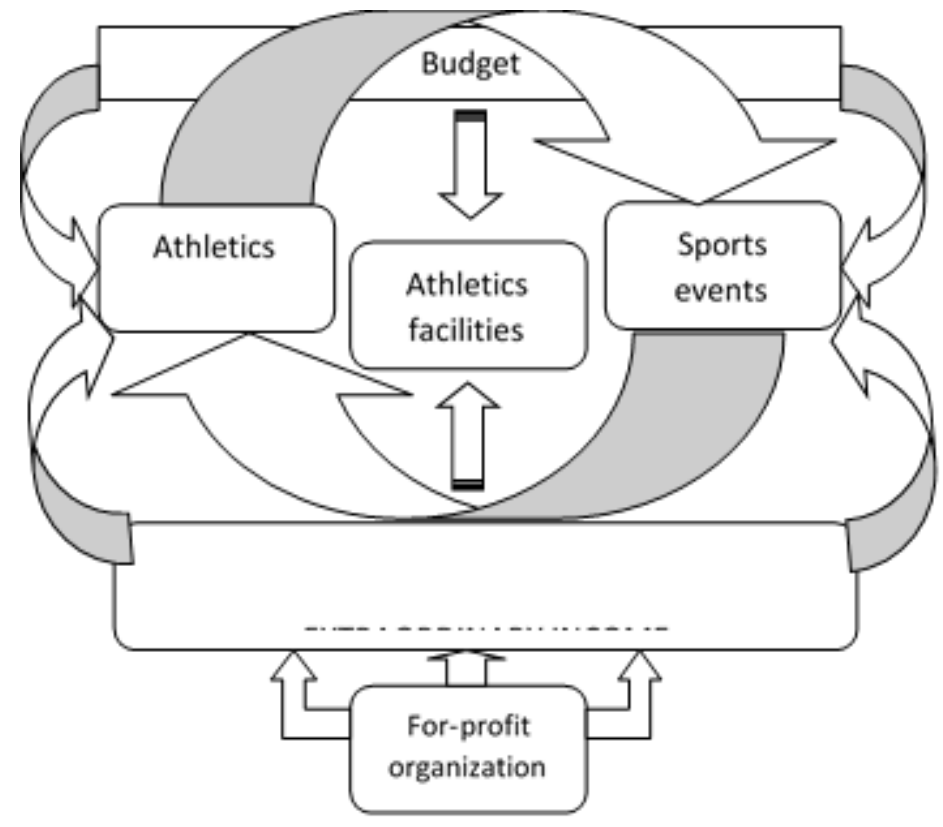

Figure 1. Traditional approach to building the economic security of leading athletes. 
This circumstance is due to the presence of a fairly narrow range of sources of income for professional athletes. The coronavirus pandemic has clearly demonstrated the vulnerability of services in the physical education and sports sector. Due to the ban on attending cultural events the mass entertainment sports suffer significant losses. It is worth noting that some sports organizations have switched to online mode (in the format of paid or free of payment video coaching). But, as practice shows, this approach can only be considered as a tool to maintain the financial condition at the lowest possible critical level. In this regard another important aspect is the fact that many professional athletes are not coaches and do not have enough experience and knowledge to run their own public/video blog which has a high potential in terms of monetization of content.

At the same time, the pandemic has generated growth in areas of economic activity such as online shopping. Largely due to the lack of development of issues of personal economic security of professional athletesleaders this type of income was outside the scope of their activities. In our opinion deductions from the sale of personal attributes or sporting goods made on the basis of sponsorship contracts could create an additional and stable source of financial income.

As we can see the level of economic security of a professional athlete is directly dependent on the success of his showing at national and international competitions. In other words, the higher the places occupied by an athlete in the most important sporting events the higher his popularity, and, consequently, his economic security. When increasing prize payments from the state the revenues from its business activities also grow.

Also, monetary payments assigned to athletes in order to stimulate and (or) support the development of their respective sports achievements have a determining role in the issue under consideration. The following types of payments are established in the Russian Federation:

1) state monthly payment to athletes;

2) state social payment to athletes;

3) state incentive payment for sports achievements;

4) payments of the President of the RF and payments of the Government of the RF for participation and victories in international sports events;

5) personal payments;

6) payments to athletes appointed by legal entities or individuals.

Table 2. Financing scheme for the first three numbers of the Russian national judo team.

\begin{tabular}{|c|c|c|c|c|c|c|c|c|c|}
\hline \multirow[b]{2}{*}{ 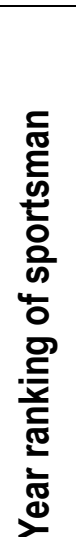 } & \multicolumn{3}{|c|}{ Sporting competition } & \multicolumn{3}{|c|}{$\begin{array}{l}\text { Preparation for } \\
\text { competitions }\end{array}$} & \multicolumn{3}{|c|}{ Training } \\
\hline & 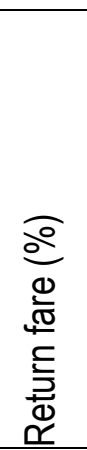 & 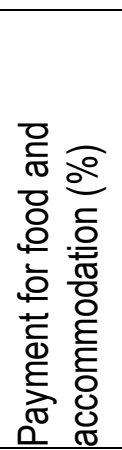 & 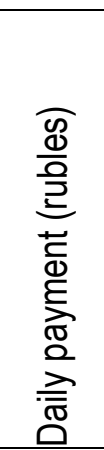 & 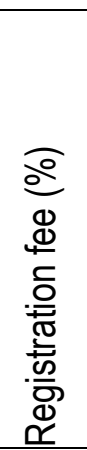 & 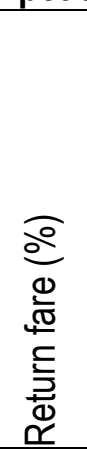 & 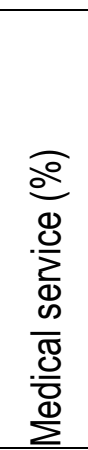 & 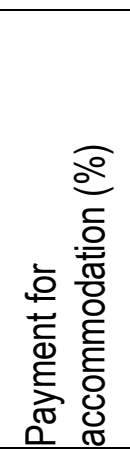 & 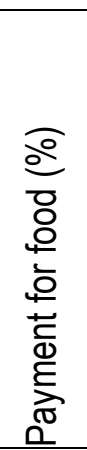 & 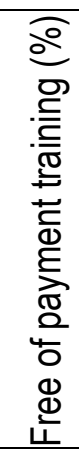 \\
\hline 1 & 100 & 100 & 4000 & 100 & 100 & 100 & 100 & 100 & 100 \\
\hline 2 & 100 & 100 & 3000 & 100 & 100 & 100 & 100 & 100 & 100 \\
\hline 3 & 0 & 0 & 1500 & 0 & 100 & 100 & 100 & 100 & 100 \\
\hline
\end{tabular}


The analysis of the situation with the financing of professional athletes in the perspective of certain sports (for example, judo) clearly demonstrates the fact that there is a significant difference in the payments (Table 2). This fact significantly complicates research in this area since large-scale fluctuations in wages can be observed at the level of a particular sport. In this case, it is advisable to take the level of the cost of living as a starting point. In the current year it is 19,544 rubles for the working-age population (the lower limit of the "red level" of economic security).

In April 2019, the information and analytical Agency RBC (RosBusinessConsulting, 2019) published the results of a survey conducted by the Financial University under the Government of Russia on the comfortable level of salaries and wages. These values significantly depending on the region, for example, residents of Moscow consider a decent salary of 100 thousand rubles, St. Petersburg - 91 thousand rubles, and Chita 50 thousand rubles (Figure 2).

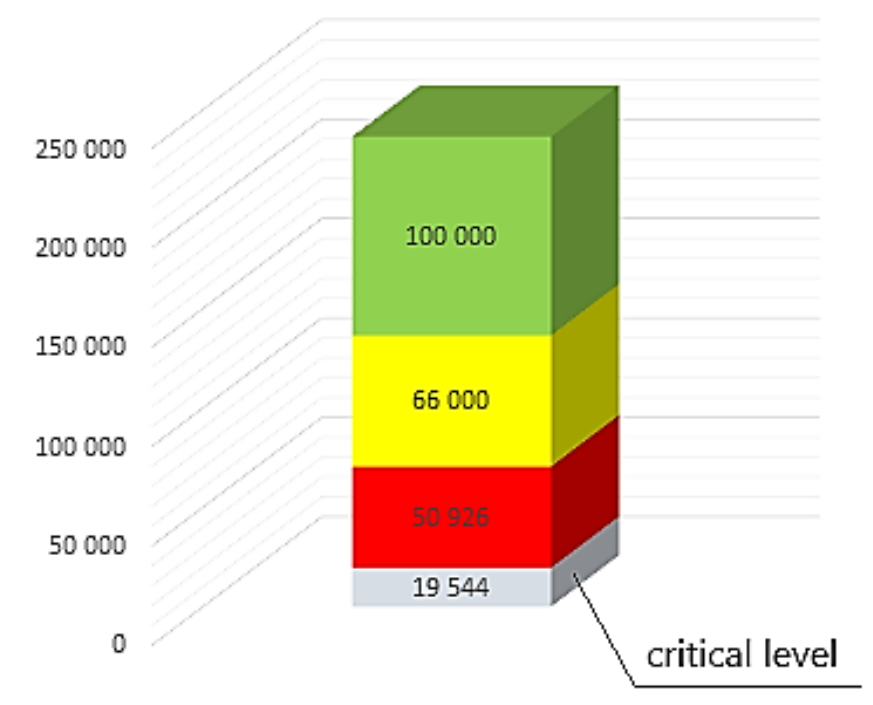

Figure 2. Levels of personal economic security of a professional athlete (rubles per month).

The average value of the desired income for Russians was 66 thousand rubles. We suggest that this value be taken as the beginning of the transition from the "yellow level" of economic security to the "green level". At the same time - according to materials published in the system ConsultantPlus (Consultant Plus, 2020) the average salary in Russia in March 2020 was 50,926 rubles. In this regard, we suggest taking this value as a transition threshold from the "red level" of economic security to the "yellow" one.

The "red level" of economic security provides the sportsman with the minimum allowable reserve of purchasing power with the subsequent possibility of forming savings when he/she come up for the border of the "yellow level" of security. An athlete remains financially dependent on state payments and income from professional activities if they are a coach/player. The possibility of making large purchases is minimized. Unplanned expenses - including those related to the implementation of professional activities - have a significant impact on its financial condition.

Getting a professional athlete into the "yellow level" of economic security creates more stable conditions for the formation of personal savings and makes it possible to realize certain categories of large purchases including at the expense of credit resources. Unplanned expenses related to the implementation of 
professional activities also have a significant impact on personal financial condition but can be completely or partially eliminated at the expense of existing savings.

The "green level" of economic security ensures stable purchasing power while the athlete himself is a representative of the middle-class lifestyle. There are opportunities for large purchases without attracting credit resources. The level of personal savings allows for spending related to professional activities without compromising their financial condition. Opportunities are being created to participate in mortgage lending programs, voluntary medical insurance and so on.

In addition to the levels the special attention should be paid to the types of economic security of professional athletes who are in the top three. In this case we propose to distinguish three types of economic security of a professional athlete: volatile, medium stability and stable. Table 3 shows the characteristics of each of the designated types.

Table 3. Types of economic security of a professional athlete.

\begin{tabular}{ll}
\hline Types of economic security & Characteristic \\
\hline Volatile & 3rd place in the group of leading athletes. Stable dependence on state \\
& support and/or private professional activities. Additional income in the \\
& format of sponsorship contracts, percentages from the sale of "personal \\
& merchandise" are either absent or are at a minimum level. \\
\hline Medium stability & 2nd place in the group of leading athletes. There is a persistent \\
& dependence on public financial support and/or private professional \\
& activities. Prospects for cooperation with leading sports brands are being \\
& formed (technical sponsorship; creation of pro-models of sports \\
& equipment and goods). In the future - if athletes have consistently high \\
results - it is possible to develop his/her own sports brand.
\end{tabular}

Tables 2 and 3 show that the higher the authority of an athlete the lower the dependence of his total income on public funding and/or private professional activities since there are broad prospects for cooperation with leading sports brands or for the formation of his own brand. Consequently, the type of economic security will be higher because of, on the one hand, there is an objective diversification of income sources, on the other hand, a professional athlete is least dependent on fluctuations in the labour market and state support measures especially those that are not of a systemic nature.

However, this approach should be clarified from the point of view of increasing the level of economic security for highly qualified professional athletes who are not in the top three. This fact is due to the presence of dynamics in the personal achievements of each athlete depending on age, physical characteristics, the system of sports nutrition and the organization of the training process. In this case it is also necessary to create additional financial support capacity that could be implemented in cases of occupational injuries and disabilities. The initiative to create an independent Fund to help professional athletes seems reasonable and appropriate in the future of the issue under study. The key approach in this case will be the idea of a minimum 
share of public finance involvement. In this regard it is necessary to use a mechanism identical to direct and indirect taxation.

In the context of a crisis in the economy of sport at the international level - largely due to the impact of the COVID-19 pandemic - on the development of a Fund project to support promising athletes who are not included in the top three leaders, on the one hand. On the other hand, it is necessary to provide a reserve of economic security during sporting events/competitions. Two problems can be identified: reducing dependence on state funding and creating a local source of financial resources based on a sports facility (structure) without reducing its financial stability. A diversified approach based on delegating the powers of financial centres to specific sports facilities (structures) that are the basis for training professional athletes and conducting sports events (competitions) of national and international scale will be crucial. In this case the Fund created on the basis of a sports facility will be an analogue of an aid Fund.

It is worth taking into account the fact that sports facilities are interested in organizing the most important sports competitions/events with the involvement of the most successful athletes. This is determined by the fact that the higher the status of the event the higher the professional level (and, consequently, the level of economic security) of professional athletes and the lower the risks of inefficient operation of the created Fund.

The fundamental source of the Fund's formation will be the "contributions" of professional athletes - it is similar to a deposit. These fees will be returned at the end of cooperation with the sports facility. In addition, it is proposed to send to the Fund part of the income from other activities of sports facilities. If a professional athlete decides to create their own sports brand the Fund will receive a commission from sales of personal merchandise. It could include the payment for assistance in supporting business processes and assistance in promoting products through the site of a sports facility, stationary and mobile retail outlets located on its territory or outside but located under its jurisdiction. One of the alternative ways to replenish the Fund is the participation of the organization-the- owner of a sports facility (structure) in operations on financial markets.

As mentioned earlier, one of the key elements of improving the personal economic security of a professional sportsman is the possibility of obtaining additional income from the sale of personal attributes. We consider it expedient and cost-effective to implement such projects on the basis of designated sports facilities.

In this case, leading athletes do not incur additional costs for developing, for example, an online store site (since it is already integrated into the main site of a sports facility). Therefore, logistics costs are reduced (regular couriers/company are involved because of they have the contract for the delivery of goods sold on the basis of a stationary store) and the project is supported by a team of lawyers, marketing specialists and economists who operate at the level of the sports facility.

The main essence of the proposed approach is that a professional athlete - in order to ensure the necessary level of economic security - can apply to the Fund for the provision of financial resources that can be used for purposes related to his professional activities and the protection of the image of the country for he stands which. For example, it can be payment of the registration fee for participation in competitions; payment of equipment; payment for food and accommodation; payment for medical care, legal services and so on. If the athlete who applied for financial support successfully performed at the competition and received remuneration, he/she is obliged to reimburse the Fund for the amount previously withdrawn by him/her. If the performance was not successful the "money borrowed" will not be returned to the Fund. In this regard, it is advisable to refer to other sources of Fund formation only as an insurance tool against such situations. In other words, if the Fund is in a balanced state there is no need to make appropriate deductions from other 
income of the sports facility/institution. The advantage of this financing scheme - or, more precisely, to ensure the personal economic security of professional athletes - will be the complete absence of the need for state funding. At the same time, the sports facility itself only serves as insurance in case of a deficit in the Fund. We propose the following structure of the Fund (Figure 3).

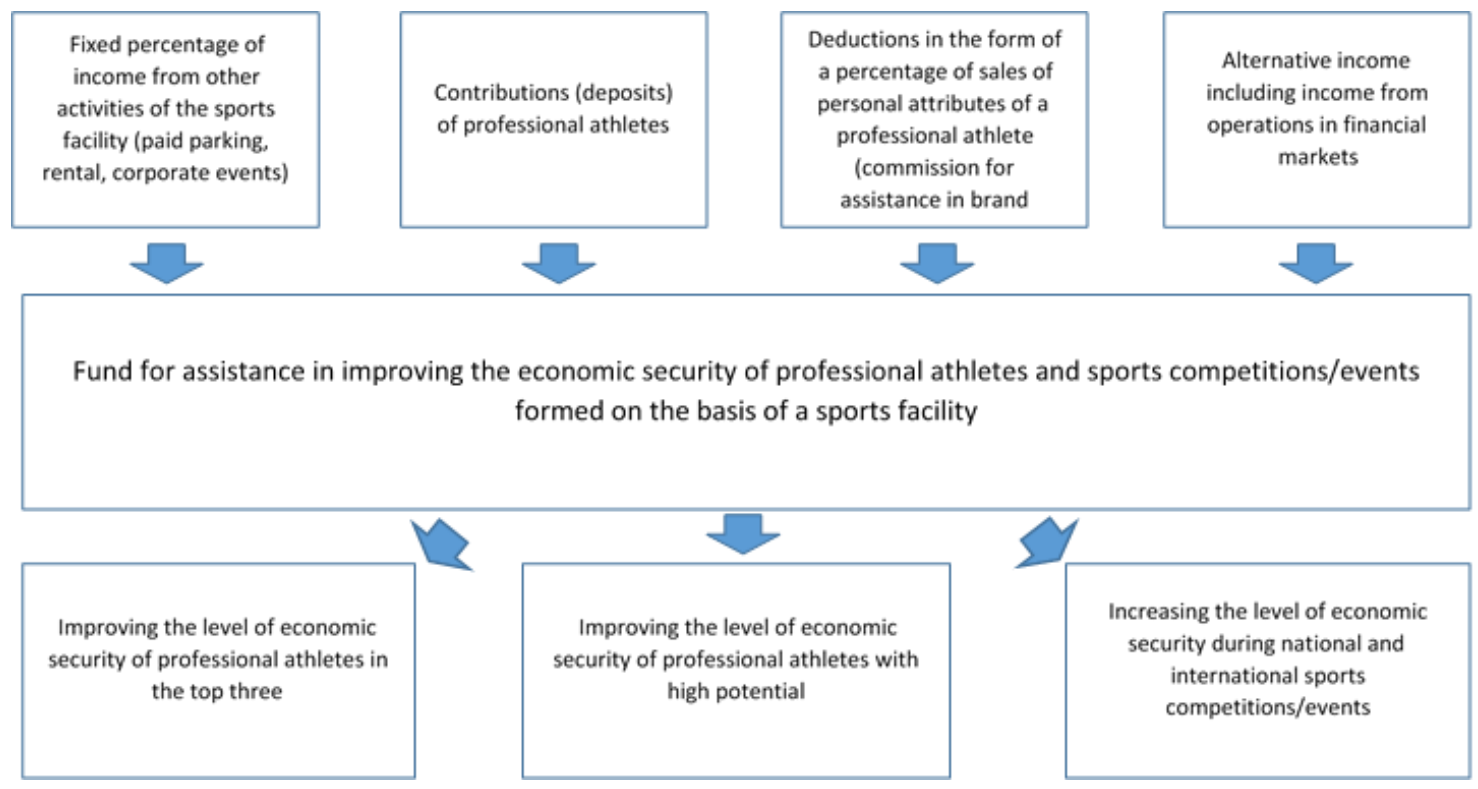

Figure 3. Project concept for creating a Fund to support professional athletes.

Table 4. Ways to support sales of products under the brand of a leading athlete and their impact on economic security.

\begin{tabular}{|c|c|c|c|}
\hline $\begin{array}{l}\text { Format of the } \\
\text { organization of a store } \\
\text { that specializes in selling } \\
\text { personal attributes } \\
\text { (sporting goods under } \\
\text { sponsorship } \\
\text { agreements) }\end{array}$ & $\begin{array}{l}\text { Brief description of the } \\
\text { object of trade }\end{array}$ & $\begin{array}{l}\text { Stages of implementation of } \\
\text { a trade company to promote } \\
\text { the personal brand of a } \\
\text { leading athlete }\end{array}$ & $\begin{array}{l}\text { The level of economic } \\
\text { security of a leading } \\
\text { athlete }\end{array}$ \\
\hline $\begin{array}{l}\text { Stationary store (located } \\
\text { on the territory of a sports } \\
\text { facility/facility) }\end{array}$ & $\begin{array}{l}\text { Sale of sports merchandise } \\
\text { and sporting goods under the } \\
\text { individual brand of a } \\
\text { professional athlete } \\
\text { permanently together with } \\
\text { other related sporting goods. } \\
\text { Five-day working hours } \\
\text { (according to the working } \\
\text { schedule). It serves as an } \\
\text { integral element of the image } \\
\text { of a sports facility. Promotion } \\
\text { of an individual brand of an } \\
\text { athlete is one of the tasks of } \\
\text { its functioning. }\end{array}$ & $\begin{array}{l}\text { The "first stage" is providing } \\
\text { attributes to fans who live } \\
\text { within the borders of the locality } \\
\text { where the sports facility is } \\
\text { located as well as residents of } \\
\text { adjacent areas. }\end{array}$ & $\begin{array}{l}\text { Exit from the "red" security } \\
\text { level to the "yellow" one. } \\
\text { Products under the } \\
\text { personal brand of the } \\
\text { athlete serve as a } \\
\text { companion product. }\end{array}$ \\
\hline $\begin{array}{l}\text { Mobile store (open on days } \\
\text { of sports } \\
\text { events/competitions, } \\
\text { operates on the territory }\end{array}$ & $\begin{array}{l}\text { The mobile point of sale for } \\
\text { merchandise is activated a } \\
\text { few hours before the start of a } \\
\text { sports competition/event and }\end{array}$ & $\begin{array}{l}\text { The "second stage" is achieved } \\
\text { through the joint work of a } \\
\text { stationary store, a mobile store } \\
\text { (during cultural events) and }\end{array}$ & $\begin{array}{l}\text { Stable "Yellow" level. } \\
\text { Brand awareness } \\
\text { increases. The product is } \\
\text { positioned as an }\end{array}$ \\
\hline
\end{tabular}




\begin{tabular}{|c|c|c|c|}
\hline $\begin{array}{l}\text { adjacent to the sports } \\
\text { facility/object), mobile } \\
\text { points of sale (sales of } \\
\text { products outside the } \\
\text { territory of the sports } \\
\text { facility) }\end{array}$ & $\begin{array}{l}\text { stops working after it is } \\
\text { completed. Short-term } \\
\text { possibility of selling attributes } \\
\text { and sporting goods with a } \\
\text { higher trade mark-up. } \\
\text { The ability to position the } \\
\text { personal brand of a leading } \\
\text { athlete "on the ground". }\end{array}$ & $\begin{array}{l}\text { mobile points of sale. Wider } \\
\text { coverage of the target audience } \\
\text { (in addition to resident buyers), } \\
\text { products are purchased by } \\
\text { visitors of the competition/event } \\
\text { who live in remote regions } \\
\text { (sports/event tourism). }\end{array}$ & $\begin{array}{l}\text { independent and full- } \\
\text { fledged position. }\end{array}$ \\
\hline Online store & $\begin{array}{l}\text { Round-the-clock order } \\
\text { acceptance mode with the } \\
\text { ability to deliver orders via } \\
\text { courier service and mail } \\
\text { including to other regions. }\end{array}$ & $\begin{array}{l}\text { The "third stage" is achieved } \\
\text { through the simultaneous } \\
\text { operation of a stationary trade } \\
\text { zone, mobile points of sale and } \\
\text { an online store. Maximum } \\
\text { coverage of the target audience } \\
\text { - delivery of attributes and } \\
\text { related sporting goods to any } \\
\text { region of the country. } \\
\text { Possibility of delivery to other } \\
\text { countries. }\end{array}$ & $\begin{array}{l}\text { "Yellow level" with the } \\
\text { possibility of entering the } \\
\text { "Green level": the brand is } \\
\text { recognizable and popular. } \\
\text { Regional sales are } \\
\text { growing. }\end{array}$ \\
\hline
\end{tabular}

As we noted above the part of the financial assets goes to the Fund due to deductions from sales of sports goods under the personal brand of leading athletes. In this regard we consider it necessary to reflect the main stages of the development of the sales system of this product, on the one hand, and to indicate the approximate planned growth of economic security of the athlete-"carrier of the brand", on the other hand (Table 4).

In conclusion, we will consider one of the options for forming a Fund to help improve the economic security of professional athletes, depending on its state (Table 5).

Table 5. An approximate algorithm for creating a Fund to promote the economic security of professional athletes.

\begin{tabular}{|c|c|c|c|c|}
\hline $\begin{array}{l}\text { State of the } \\
\text { Fund }\end{array}$ & $\begin{array}{l}\text { Fixed percentage of } \\
\text { income from other } \\
\text { activities of a } \\
\text { sports facility (\%) }\end{array}$ & $\begin{array}{l}\text { Contributions } \\
\text { (deposits) of } \\
\text { professional } \\
\text { athletes (\%) }\end{array}$ & $\begin{array}{l}\text { Deductions in the } \\
\text { form of a percentage } \\
\text { of sales of personal } \\
\text { merchandise of a } \\
\text { professional athlete } \\
(\%)\end{array}$ & $\begin{array}{l}\text { Alternative } \\
\text { income including } \\
\text { income from } \\
\text { operations in } \\
\text { financial markets } \\
(\%)\end{array}$ \\
\hline Balanced & 0 & 100 & 0 & 0 \\
\hline $\begin{array}{l}\text { Minor deficit } \\
\text { (up to } 10 \% \text { ) }\end{array}$ & 0 & 90 & 0 & 10 \\
\hline $\begin{array}{l}\text { Sustained deficit } \\
(10-30 \%)\end{array}$ & 10 & 70 & 10 & 10 \\
\hline $\begin{array}{l}\text { The critical deficit } \\
(30 \%-50 \%)\end{array}$ & 10 & 50 & 20 & 20 \\
\hline $\begin{array}{l}\text { Crisis situation } \\
\text { (more than } 50 \% \text { ) }\end{array}$ & 20 & 30 & 20 & 30 \\
\hline
\end{tabular}

Summarizing the above we can come to the following conclusions. Issues of personal economic security of professional athletes today form a separate complex problem area. In the light of the issues studied, in our opinion, the most appropriate idea is to develop and promote individual sports brands of leading athletes, on 
the one hand, and to form a trust Fund designed on the principle of mutual assistance funds (aid fund), on the other hand. A key role both in the development and promotion of the brand and in the formation of the trust Fund will play sporting facilities where the training process is organized and sports competitions/events for national and international scales are held.

\section{REFERENCES}

Beilin, M. V. (2014). Axiological discourse of economic security of society. In the collection: Economics. Society. Person. Belgorod state technological University named after V. G. Shukhov, pp. 314-324.

Blakyta, G., Ganushchak, T. (2018). Enterprise financial security as a component of the economic security of the state. Investment Management and Financial Innovations, Volume 15, Issue 2, 248256. https://doi.org/10.21511/imfi.15(2).2018.22

Consultant Plus (2020). The average monthly salary in the Russian Federation as a whole (the Material was prepared by ConsultantPlus specialists according to Rosstat data). Retrieved from http://www.consultant.ru/document/cons doc_LAW_326052/

Bukharina, I. L., Zhuravleva, A. N., Dvoeglazova, A. A., Kamasheva, A. A., Muhametnagimovna, S. A., \& Kuzmin, P. A. (2014). Physiological and biochemical characteristic features of small-leaved lime(tilia cordata mill.) in urban environment. Advances in Environmental Biology, 8(13), 79-83.

Dzhavatov, D. K., Sverdlikova, E. A., Sokolov, M. S., Avdeeva, O. A., \& Yavkin, G. P. (2018). The influence of innovation on social and economic development of the russian regions. European Research Studies Journal, 21(Special Issue 2), 767-776.

Dunets, A. N.; Vakhrushev, I. B.; Sukhova, M. G.; Sokolov, M. S.; Utkina, K. M.; Shichiyakh, R. A. (2019). Selection of strategic priorities for sustainable development of tourism in a mountain region: concentration of tourist infrastructure or nature-oriented tourism, Entrepreneurship and Sustainability Issues 7(2): 1217-1229. https://doi.org/10.9770/jesi.2019.7.2(29)

Dunets, A. N., Yankovskaya, V. V., Plisova, A. B., Mikhailova, M. V., Vakhrushev, I. B., \& Aleshko, R. A. (2020). Health tourism in low mountains: A case study. Entrepreneurship and Sustainability Issues, 7(3), 2213-2227. https://doi.org/10.9770/jesi.2020.7.3(50)

Feofanov, N. Yu. (2005). Analysis of revenue from the sale of sports merchandise by professional clubs of game sports. Economic analysis: theory and practice, no. 7 (40), pp. 53-57.

Filatova, I. V. (2017). Challenges and threats to economic security in the framework of the implementation of the economic security strategy of the Russian Federation until 2030 Bulletin of the Moscow University of the Ministry of internal Affairs of Russia, no. 6, pp. 263-266.

Ivanova, V., Poltarykhin, A., Szromnik, A., \& Anichkina, O. (2019). Economic policy for country's digitalization: A case study. Entrepreneurship and Sustainability Issues, 7(1), 649-661. https://doi.org/10.9770/jesi.2019.7.1(46)

Klychova, G. et al. (2019). Methodological tools to ensure economic security in the personnel management system of enterprises. E3S Web of Conferences 135, 04008 ITESE-2019, 1-13. https://doi.org/10.1051/e3sconf/201913504008

Kuzmin, P. A., Bukharina, I. L., \& Kuzmina, A. M. (2018). The reaction of woody plants to growing conditions in the man-made environment. International Journal of Civil Engineering and Technology, $9(11), 878-887$.

Masood, O.; Tvaronavičienè, M.; Javaria, K. (2019). Impact of oil prices on stock return: evidence from G7 countries, Insights into Regional Development 1(2): 129-137. https://doi.org/10.9770/ird.2019.1.2(4) 
Melnyk, S.et al.(2020). Anti-crisis personnel management in the process of ensuring the economic security of the enterprise. Business: Theory and Practice, 21(1), 272-281. https://doi.org/10.3846/btp.2020.11438

Poltarykhin, A., Dibrova Z., Kovaleva I., Vasyutkina L., Potekhina E., \& Zinisha O. (2020). World experience in the application of antitrust regulation and compliance system. Entrepreneurship and Sustainability Issues, Year 2020. Volume 7 Number 3. Page 2313-2325. https://doi.org/10.9770/jesi.2020.7.3(57)

Pryazhnikova, O. N. (2017). Economic security in the context of personal security. Economic and social problems of Russia, no. 1, pp. 84-97.

RosBusinessConsulting (2019, April). The Russians called the salary necessary for a "decent life". Retrieved from https://www.rbc.rul

Rukhovets, L. V. (2016). Protection of personal savings of citizens as a tool for ensuring the economic security of the state. In the collection: security, personality, society: socio-legal aspects. Collection of articles based on the materials of the all-Russian round table. North-Western branch of the RUSSIAN state University of justice, pp. 201-206.

Sedov, S. A., Valiev, I. N., Kuzmin, P. A., \& Sharifullina, A. M. (2014). On the issue of environmentoriented measures to eliminate the causes and reduce the effects of technogenic impact on the territory. Biosciences Biotechnology Research Asia, 11, 169-172. https://doi.org/10.13005/bbra/1456

Sylvanus A. Ehikioya, Adepele A. Olukunle (2019). A Formal Model of Distributed Security for Electronic Commerce Transactions Systems. International Journal of Networked and Distributed Computing, 7(2), 68-84. https://doi.org/10.2991/ijndc.k.190326.003

Tarman, B. (2016). Innovation and Education. Research in Social Sciences and Technology, 1(1). https://doi.org/10.46303/ressat.01.01.4

Turgaeva, A. A., Kashirskaya, L. V., Zurnadzhyants, Y. A., Latysheva, O. A., Pustokhina, I. V., \& Sevbitov, A. V. (2020). Assessment of the financial security of insurance companies in the organization of internal control. Entrepreneurship and Sustainability Issues, 7(3), 2243-2254. https://doi.org/10.9770/jesi.2020.7.3(52)

Voronina, V. T. (2017). Dynamics of development and financing of sports facilities in Russia. Innov: electronic scientific journal, no. 4 (33), p. 20.

Vedomosti (2018, June). "For the first time "Spartak" revealed its revenue from ticket sales and TV rights." Retrieved from https://www.vedomosti.ru

\section{(@) $\odot \Theta \Theta$}

This work is licensed under a Attribution-NonCommercial-NoDerivatives 4.0 International (CC BY-NC-ND 4.0). 